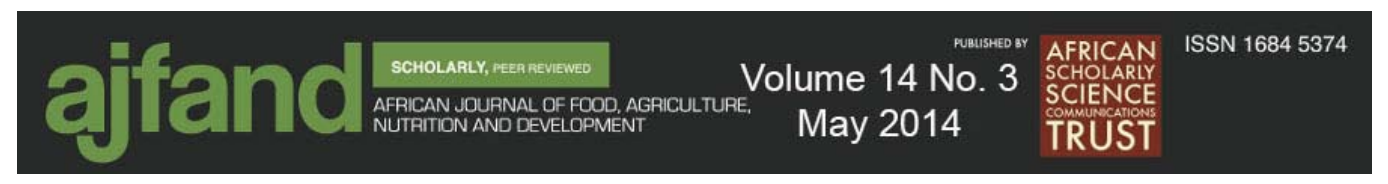

\title{
ACCEPTABILITY AND NUTRITIONAL CONTRIBUTION OF GRAIN AMARANTH RECIPES IN UGANDA
}

Tibagonzeka $\mathbf{J}^{1}$, Wambete $\mathbf{J}^{1}$, Muyinda $\mathrm{AM}^{2}$, Nakimbugwe $\mathrm{D}^{1}$ and $\mathrm{JH}$ Muyonga ${ }^{{ }^{*}}$

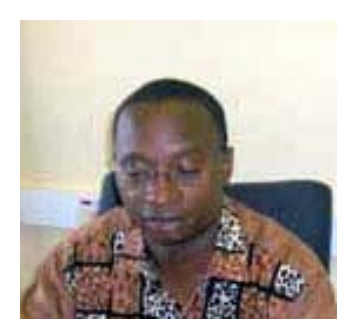

John Muyonga

*Corresponding author's email: hmuyonga@yahoo.com

${ }^{1}$ School of Food Technology, Nutrition \& Bioengineering, Makerere University, Kampala, Uganda P.O. Box 7062, Kampala Uganda

${ }^{2}$ Volunteer Efforts for Development Concern, Kamuli, Uganda. 


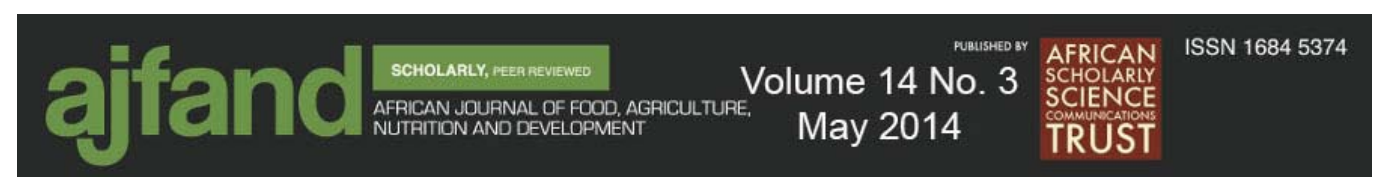

\begin{abstract}
Grain amaranth is a highly nutritious crop. It is high in proteins and its proteins are of high quality. Compared to common starchy staples, grain amaranth also contains higher levels calcium, zinc, iron as well as vitamins A, E and folic acid. Grain amaranth has also been reported to exhibit nutraceutical properties. Despite its high nutritional value and nutraceutical properties, grain amaranth consumption in Uganda is low. This study was undertaken to evaluate the acceptance of grain amaranth containing recipes and to determine their potential nutritional contribution. A 24 hour recall was conducted on a sample of 420 respondents drawn from nine sub-counties, three from each of three districts: The results of the 24 hour recall were used to calculate nutritional quality indices. The 24 hour recall results showed low nutritional quality indices for zinc, calcium, niacin, thiamin and lipids. In addition, diets for $74 \%$ of respondents were low in iron. A total of 17 recipes containing grain amaranth and other locally produced foods were then developed with the aim of producing products with enhanced zinc, calcium, niacin, thiamin, iron and energy content. Products prepared based on the developed recipes were subjected to proximate analysis and sensory evaluation while the recipes were assessed by farmer groups for acceptability. All the products developed were found to be highly acceptable, all scoring $\geq 7.5$ on nine point scale. The presence of grain amaranth in the products enhanced the nutrient content of most foods, when compared to the traditional recipes without grain amaranth. The most marked positive changes attributable to presence of grain amaranth in the food formulations were observed in the levels of $\mathrm{Zn}, \mathrm{Fe}$ and $\mathrm{Ca}$. Grain amaranth markedly enhanced the nutrient content for the starchy staple dishes which dominate diets of low income households in the communities studied. These findings show that if incorporated into locally consumed dishes, grain amaranth would fill some of the dietary nutrient gaps. The high acceptability of the products containing grain amaranth and the recipes tested showed high potential for grain amaranth adoption once the recipes are disseminated.
\end{abstract}

Key words: Amaranth, dietary assessment, sensory evaluation 


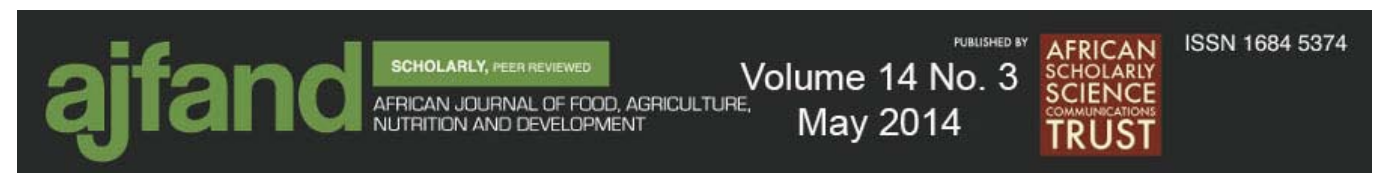

\section{INTRODUCTION}

Amaranth (Amaranthus spp) is an herbaceous annual plant with upright growth habit, cultivated for both its seeds, which are used as a grain, and its leaves which are used as vegetables. Both leaves and seeds contain protein of unusually high quality [1]. Amaranth is often called a pseudocereal because it is used much like cereal grains although it is not in the grass family. Grain amaranth belongs to the cosmopolitan Amaranthus genus of some 60 species [2]. The most important species include $A$. hypochondriacus, A. cruentus (grain type), and A. tricolor, A. dubius, A. lividus, A. creuntus, A. palmeri and A. hybridus (vegetable type) [3]. Grain amaranths and many other amaranth species show tremendous potential for human consumption and other uses, and are particularly promising as a remedy for hunger and malnutrition in developing countries [2].

Grain amaranth is a relatively new food crop in Uganda. To facilitate expansion in its consumption, there is need to develop locally acceptable recipes and formulations. Current staple diets for most of the resource poor people in Uganda are dominated by starchy staples. These staples are typically low in lipids, protein, vitamins and minerals. Grain amaranth has higher quality and quantity of protein than most staples and the amino acid composition of its protein compares with the protein standard for good health [4]. Amaranth grain contains twice the level of calcium in milk, five times the level of iron in wheat, higher potassium, phosphorous and vitamins $\mathrm{A}, \mathrm{E}$ and folic acid than cereal grains [5]. Amaranth grain also consists of $6-10 \%$ oil, which is predominantly unsaturated and is high in linoleic acid [6], an essential fatty acid. Grain amaranth would, if adopted for consumption, therefore, enrich local diets in different parts of Uganda.

Consumption of grain amaranth has been reported to have nutritional and health benefits, ranging from a general improvement in well-being to prevention and improvement of specific ailments and symptoms including recovery of severely malnourished children and an increase in the body mass index of people formerly wasted by HIV/AIDS [7,8]. Some specific nutritional and health benefits of amaranth consumption have been elucidated. Amaranth oil has been shown, in animal studies, to lower total serum triglycerides and levels of low density lipoproteins (LDL) [9]. Similar effects have been reported in humans [10]. High levels of serum LDL are associated with coronary heart disease. The serum LDL lowering effect of amaranth has been attributed to the tocotrienols (unsaturated forms of vitamin E) and squalene in amaranth oil. These compounds affect cholesterol biosynthesis in humans [10]. They are also believed to have anti-tumor and anti-oxidative activity [11], pointing to potential anti-cancer effects. Supplementation of patients with coronary heart disease with amaranth oil has been shown to contribute to decrease in body weight, a decrease or disappearance of headaches, weakness, increased fatigability, shortness of breath during physical activity, edema of the legs towards evenings and feeling of intermission of heart function in most patients [10]. Animal studies have shown that supplementation of diets with amaranth grain and amaranth oil improves glucose and 


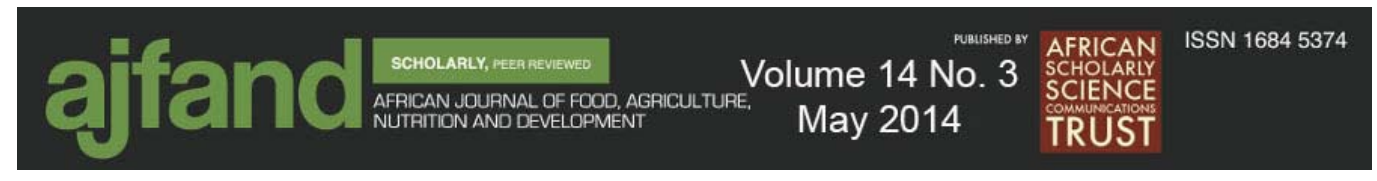

lipid metabolism [12]. The fasting serum glucose levels and the glucose tolerance of the diabetic rats were both improved.

The aim of this study was to identify forms of incorporating grain amaranth to local diets in Uganda to address current dietary deficiencies. Elsewhere, grain amaranth has been used as seeds or flour to make a wide variety of products, including cookies, cakes, pancakes, bread muffins, crackers, pasta and other bakery products [3].

\section{MATERIALS AND METHODS}

\section{Determination of baseline dietary deficiencies}

A baseline survey was conducted in three districts of Uganda which included Apac, Kamuli and Nakasongola to determine dietary nutrient gaps. The selected districts represent 3 different agro-ecological and socio-cultural settings. Apac, which is located in Northern Uganda, is dominated by mixed farming. The main foods grown and consumed in this district include millet, sesame, maize, beans, sweet potatoes, cassava and groundnuts. Nakasongola is located in the Central part of Uganda. Most of the people in Nakasongola district are pastoralists. Important food crops in Nakasongola include cassava, maize, sweet potatoes, sorghum and millet. Kamuli district is located in Southeastern part of Uganda. Crop production is the most important economic activity and the main crops grown include sweet potatoes, rice, beans, bananas, maize, millet, groundnuts, citrus fruits and mangoes. The nutrient intake levels were determined based on 24 hour recall [13] data. The nutrient intake levels were compared to recommended intakes and the proportion of subjects whose intake was lower than that recommended levels for the different nutrients were determined. The Hansen's nutritional quality indices (NQI) were also derived and used to identify nutritional deficiencies [14].

\section{Development of grain amaranth containing recipes}

Recipes were developed to produce foods with elevated levels of nutrients identified to be deficient based on the NQI values obtained and absolute nutrient intake levels. Locally available foods with high levels of nutrients found to be deficient in the diets (from the baseline dietary survey) were identified, based documented nutritional composition.

Maize, cassava, rice, beans and wheat, which are major staples in all the study areas, were used as base foods for complementation with identified nutrient rich foods. All these foods were combined with grain amaranth and other locally available foods in different ratios. Traditional preparation methods, including those already used in preparation of grain amaranth by local communities, were then used to produce different food products. The developed products were subjected to a nine-point hedonic scale acceptability analysis. Panels of five sensory analysts were used to undertake preliminary product analysis during recipe development. The final formulations used for the different food products are provided in Table 1. 


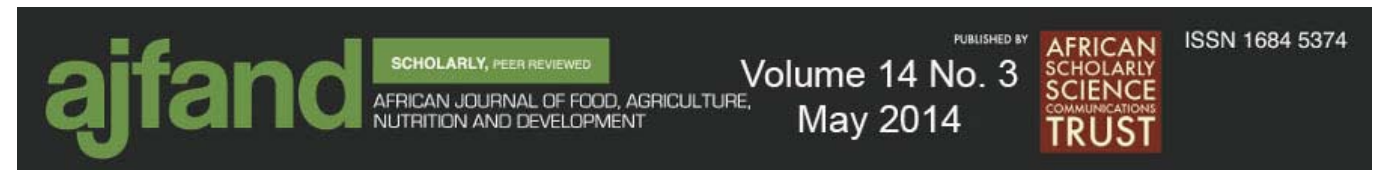

\section{Sensory analyses of the developed products}

Sensory evaluation was conducted using a panel of 54 (35 females and 19 males) untrained panelists selected from volunteers among the Makerere University student and staff community. Before the study, all panelists were briefed about the procedure and each had to verbally consent to participation. All participants were non smokers, fluent in English, self reported to have normal taste and smell sensitivity. Panelists were requested to refrain from eating or drinking for at least 1 hour before the scheduled time for product tasting. The panelists assessed the acceptance of the products using a nine point hedonic scale. Each of the recipes was also analysed by six farmer groups (two from each of the three participating districts) who scored both the products and the production recipes using a five point scale, with one as highly unacceptable and five as highly acceptable. The groups were required to derive the score through consensus, after trying out the recipes and testing the resulting products.

\section{Determination of nutritional value}

The crude protein, fat, total ash and moisture contents of the food products were determined using AOAC methods [15]. Moisture content, total ash, crude fat and crude protein were determined by oven method, hot furnace, Soxhlet and Kjeldahl (N $\mathrm{x}$ 6.25) methods, respectively. Carbohydrates were estimated based on the nitrogen free extract and energy was derived by calculation based on the energy values of the macro-components.

The dietary fiber content of the foods was determined by the gravimetric method [16]. About $0.5 \mathrm{~g}$ of the sample was weighed into a $600 \mathrm{ml}$ flask, $50 \mathrm{ml}$ of acid detergent fiber were added and the mixture boiled for one hour. The mixture was then filtered over a Buchner funnel connected to a vacuum pump using a sinter glass. The sinterglass crucibles were taken to the oven maintained at $100^{\circ} \mathrm{C}$ for 45 minutes to drive off the moisture. Dietary fiber was obtained as the difference between the weight of the empty sinter-glass and that after removal from the oven.

The iron (Fe) and zinc ( $\mathrm{Zn})$ contents of the food were determined using Atomic Absorption Spectrophotometer, Perkin-Elmer 2380 [15]. Calcium was determined using flame photometry. All values were expressed in $\mathrm{mg} / 100 \mathrm{~g}$ of sample.

The grain amaranth used in the study was cleaned by passing through multiple size sieves to minimize contamination which is a problem is small seed crops. The other materials used were obtained from local markets. For all chemical analyses, 3 different experiments were undertaken and samples were analysed in triplicate.

\section{Data Analysis}

Data were analyzed using Statistical Package for Social Scientists Version 16. Descriptive statistics (means and standard deviations) were derived for the different products for all attributes measured. Sensory evaluation data were also subjected to analysis of variance. Mean separation was attained using the least square difference method. 


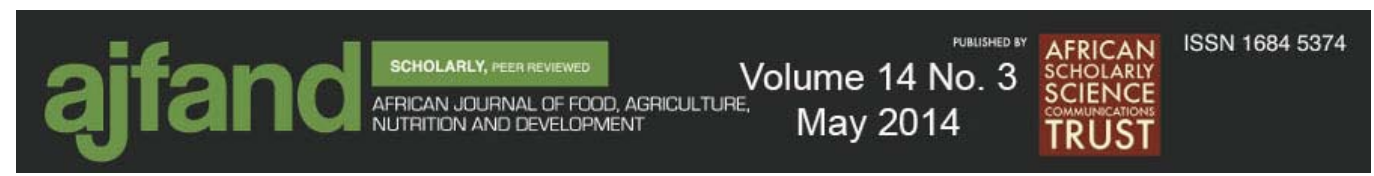

\section{RESULTS}

Dietary nutrient inadequacies based on Nutritional quality indices

The mean NQI for zinc, calcium, niacin, thiamin and lipids were as shown below (Figure 1), indicating a need for dietary enrichment with respect to these nutrients. It was also observed that $74.1 \%$ of households studied had diets deficient in iron (Figure 2).

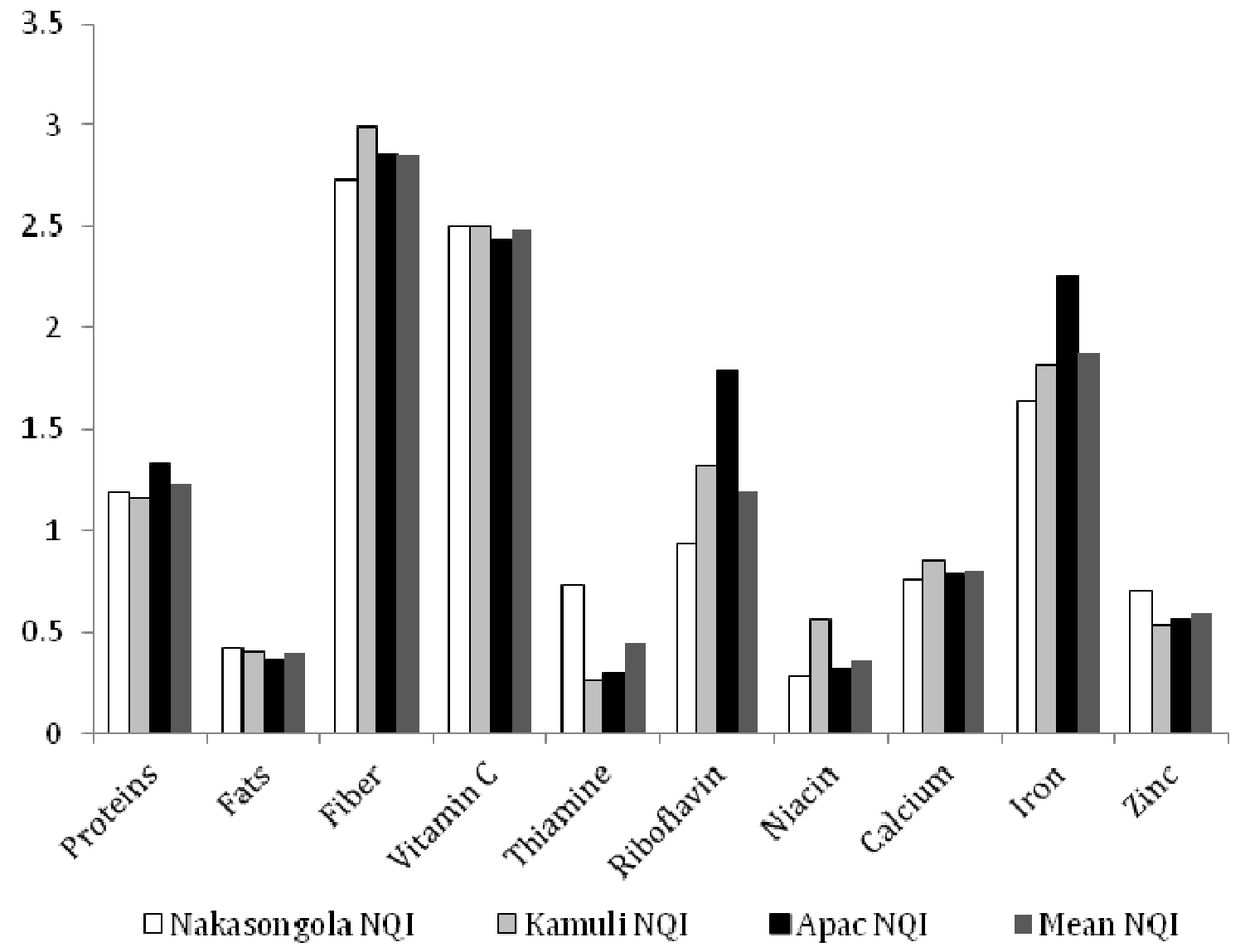

Figure 1: Nutritional quality index (NQI) of foods consumed by farmer households in Nakasongola, Kamuli and Apac districts based on 24 hour recall data 

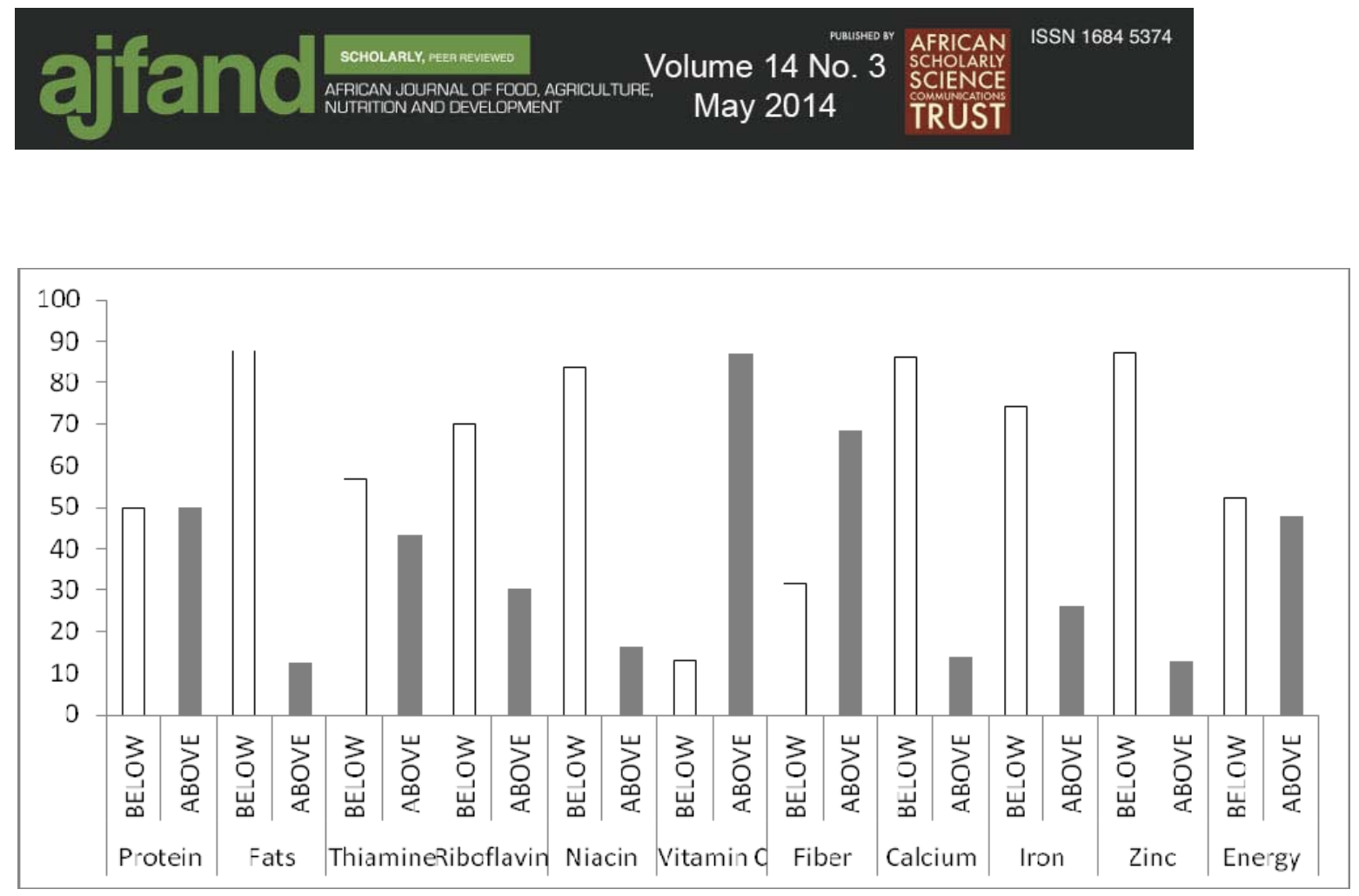

Figure 2: Distribution (\%) of study population based on adequacy of the intake of the different nutrients

Based on the food availability in the districts and their nutritional profile, different foods were identified (Table 2) for enrichment of recipes with the identified deficient nutrients.

\section{Sensory Evaluation of the developed products}

All the products developed were found to be highly acceptable (Table 3), all scoring $\geq 7.5$ on a nine point scale. This shows high potential for the adoption of the developed products.

\section{Nutritional value of the developed grain amaranth containing products}

Incorporation of the different foods identified as good sources of nutrients found to be deficient in diets of people in the three districts, generally led to products with enhanced levels of these target nutrients (Table 4). Sesame, soybeans and peanuts, in addition to contributing to nutrient enrichment, also enhanced the energy content of the foods to which they were added.

The presence of grain amaranth in the products led to a positive change in the nutrient content of most foods, when compared to the traditional recipes without grain amaranth (Table 5). The most marked positive changes attributable to presence of grain amaranth in the food formulations were recorded in the levels of the minerals ( $\mathrm{Zn}, \mathrm{Fe}$ and $\mathrm{Ca})$. Grain amaranth markedly enhanced the nutrient content for cassava meal. It also generally enhanced nutrient content for maize, millet and rice albeit to a lower extent. This shows the value of incorporating grain amaranth in diets dominated by traditional starchy staples. 


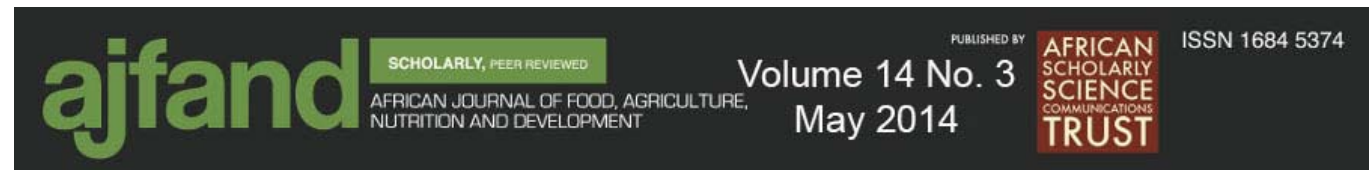

On the other hand, in sesame balls, grain amaranth incorporation was found to cause a reduction in the levels of all nutrients except protein. Generally the benefit of incorporating grain amaranth into oil seeds and pulses was lower than observed for starchy staples. Products containing sesame generally exhibited very high calcium content while GA tea masala, a product spiced with a locally sold ginger based spice normally used in tea, contained high levels of iron.

\section{Recipe and food products community acceptance}

A total of 15 of the 17 developed recipes were rated at $\geq 4$ on a five point scale (Table 6) by farmer groups. The rice meal and bean sauce recipes were the only two to score below four. This shows that the recipes were generally acceptable to the communities in the three districts. There were no significant differences $(p>0.05)$ in the scores given to the different recipes by farmer groups in the three districts.

The products made using the developed recipes were also found to be highly acceptable by the farmer groups, with 16 out of 17 scoring $\geq 4$ on a scale of five (Table 7). The high acceptability of both recipes and products shows high potential for increased consumption of grain amaranth once the recipes are widely disseminated.

\section{DISCUSSION}

Malnutrition and nutritional deficiencies are serious problems for Uganda and this is to a large extent attributable to the poor quality of diets [17]. Dietary inadequacy with respect to iron, zinc, calcium and folic acid has previously been reported in a national food consumption survey [18]. A narrow range of staples, comprising cereals, plantain, roots and tubers dominate diets for most households in Uganda, accounting for approximately $70 \%$ of foods consumed [19]. These staples are largely deficient in important nutrients needed for normal human nutrition and health. Food based interventions ensure strong linkage between food production and consumption [20]. This helps to ensure sustained alleviation of malnutrition. There is, therefore, need to identify foods which can be used to alleviate malnutrition, especially among resource constrained communities. Grain amaranth is a fast growing, high yielding, stress resistant, nutritious crop with potential to contribute to the alleviation of malnutrition and nutritional deficiencies. Grain amaranth also fits well in the food habits of rural communities in Uganda since it can be used to make commonly consumed dishes such as gruels, stiff porridges, fried snacks and sauces. Results from this study show that grain amaranth is quite acceptable for consumption by communities in Kamuli, Nakasongola and Apac districts, Uganda and the products made with grain amaranth are of superior nutritional value compared to dishes without grain amaranth. Promotion of grain amaranth production and consumption should, therefore, be undertaken as an intervention towards alleviation of malnutrition. Such promotion should include nutrition education to inform the communities of the nutritional value of grain amaranth. It has been recognized that knowledge of the nutritional value of new crops promotes their adoption [21]. Methods that promote nutrient bioavailability from grains such as malting could be adopted to ensure even higher nutritional 


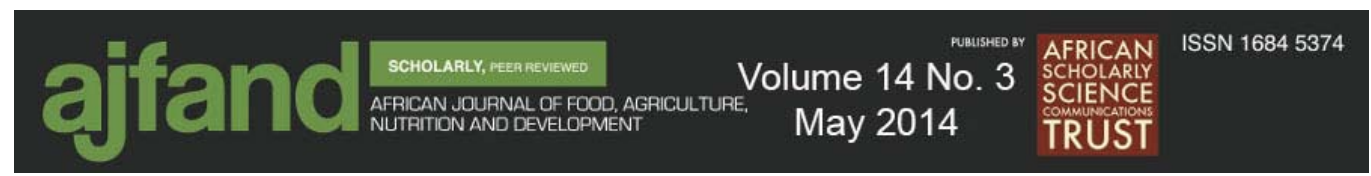

benefits from grain amaranth. Results for nutritional composition of the different products analysed revealed exceptionally high calcium content among those containing sesame. This is consistent with the fact that sesame is a rich source of calcium [22]. Ginger masala on the other hand had high values of iron (168 $\mathrm{mg} / 100 \mathrm{~g}$ ). This may have resulted from contamination during milling of the pilau masala, an ingredient containing cardamom and a number of other spices which was purchased from local markets. There is widespread use of mills made of cast iron in Uganda. These could be a source of iron contamination in flours.

\section{CONCLUSION}

This study has demonstrated that grain amaranth has potential to contribute to the alleviation of dietary nutritional deficiencies. The recipes developed through this study were found to contain enhanced levels of the nutrients previously reported to be inadequate in the diets in the 3 study districts. These recipes were not only able to fill the nutritional gaps but were also found to be highly acceptable to the farmers in the rural households of three different districts in Uganda. Once widely disseminated and adopted, these recipes are likely to markedly contribute to improved nutrition in the three districts. Dissemination of the recipes is now on-going and this will be followed by evaluation of their adoption.

\section{ACKNOWLEDGEMENT}

This study was funded by McKnight Foundation under the Collaborative Crop Research Programme. 


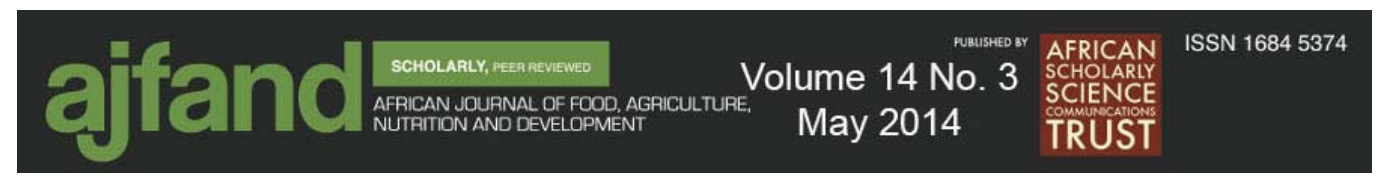

Table 1: Formulation used for producing grain amaranth (GA) containing food products

\begin{tabular}{|c|c|c|}
\hline Food products & $\begin{array}{l}\text { Ingredients and their mixing } \\
\text { proportions }\end{array}$ & Preparation method \\
\hline Chapatti & $\begin{array}{l}\text { Wheat flour }(1400 \mathrm{~g}), \text { popped } \\
\text { powdered grain amaranth }(600 \mathrm{~g}) \text {, } \\
\text { water }(1000 \mathrm{ml}) \text {, grated carrots } \\
(156 \mathrm{~g}), \text { grated onions }(86 \mathrm{~g}) \text {, } \\
\text { cooking oil }(35 \mathrm{ml}) \text { and salt }(15 \\
\mathrm{g})\end{array}$ & $\begin{array}{l}\text { Ingredients mixed, kneaded into dough. } \\
\text { Portions ( } 95 \mathrm{~g} \text { ) of dough rolled into flat } \\
\text { round shapes (about } 12 \mathrm{~cm} \text { diameter and } \\
<1 \mathrm{~cm} \text { thickness), pan fried with gas flame } \\
\text { while turning to have both sides heated. }\end{array}$ \\
\hline Baggia & $\begin{array}{l}\text { Cassava flour }(500 \mathrm{~g}), \text { water } \\
(1000 \mathrm{ml}), \text { roasted powdered } \\
\text { soybean }(300 \mathrm{~g}), \quad \text { popped } \\
\text { powdered grain amaranth }(200 \mathrm{~g}), \\
\text { ground fresh onions }(43 \mathrm{~g}), \\
\text { ground fresh ginger }(17 \mathrm{~g}) \text { an salt } \\
(15 \mathrm{~g})\end{array}$ & $\begin{array}{l}\text { Solid ingredients mixed using a wooden } \\
\text { stirrer, water added gradually while } \\
\text { stirring. Resulting paste cold extruded } \\
\text { using Baggia machine and deep fried over a } \\
\text { charcoal stove fire until golden brown and } \\
\text { crunchy }\end{array}$ \\
\hline Pancakes & $\begin{array}{l}\text { Cassava flour }(500 \mathrm{~g}) \text {, popped } \\
\text { grain amaranth flour }(250 \mathrm{~g}), \\
\text { freshly peeled sweet bananas }(560 \\
\mathrm{g}) \text {, ginger }(17 \mathrm{~g}) \text { and cooking oil } \\
(1 \text { litre })\end{array}$ & $\begin{array}{l}\text { Cassava flour and popped grain amaranth } \\
\text { flour thoroughly mixed and sifted then } \\
\text { blended with sweet bananas and ground } \\
\text { ginger. The dough was rolled, shaped and } \\
\text { deep fried }\end{array}$ \\
\hline $\begin{array}{l}\text { GA-sesame } \\
\text { balls }\end{array}$ & $\begin{array}{l}\text { Roasted sesame }(100 \mathrm{~g}) \text { popped } \\
\text { G.A }(100 \mathrm{~g}) \text { and granular sugar } \\
(100 \mathrm{~g}) .\end{array}$ & $\begin{array}{l}\text { Sugar was melted in a saucepan and the } \\
\text { grains while stirring constantly using a } \\
\text { metal spoon. Ladleful scoops of the grain- } \\
\text { molten sugar mixture were hand-rolled } \\
\text { into round balls and left to set }\end{array}$ \\
\hline $\begin{array}{l}\text { GA-bean } \\
\text { Sauce }\end{array}$ & $\begin{array}{l}\text { Dry beans }(300 \mathrm{~g}) \text {, popped G.A } \\
\text { flour }(200 \mathrm{~g}) .\end{array}$ & $\begin{array}{l}\text { Beans soaked in 3liters of clean cold } \\
\text { water overnight. The testa were removed } \\
\text { and the beans cooked, mashed and } \\
\text { kneaded with GA flour. Resulting dough } \\
\text { shaped and dried. Preparation of product } \\
\text { done by boiling or frying and addition of } \\
\text { spices and salt as desired }\end{array}$ \\
\hline $\begin{array}{l}\text { GA-sesame } \\
\text { instant } \\
\text { porridge }\end{array}$ & $\begin{array}{l}\text { Sesame G.A (600 g), granular } \\
\text { sugar }(100 \mathrm{~g}) \text { and water }\end{array}$ & $\begin{array}{l}\text { The grain was milled and blended with } \\
\text { sugar. The resulting flour was used to } \\
\text { make porridge by mixing with water to } \\
\text { desired consistency }\end{array}$ \\
\hline $\begin{array}{l}\text { GA-millet } \\
\text { porridge }\end{array}$ & $\begin{array}{l}\text { Roasted millet flour }(500 \mathrm{~g}) \text { and } \\
\text { roasted G.A flour }(500 \mathrm{~g})\end{array}$ & $\begin{array}{l}\text { The two flours were mixed and porridge } \\
\text { was made from the flour using } \\
\text { conventional boiling method. }\end{array}$ \\
\hline
\end{tabular}




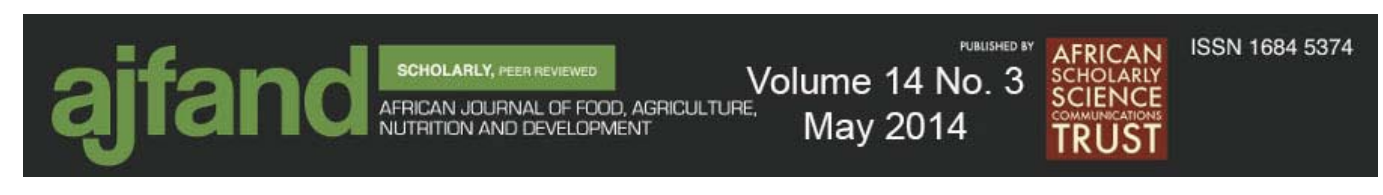

\begin{tabular}{|c|c|c|}
\hline $\begin{array}{l}\text { GA-maize } \\
\text { porridge }\end{array}$ & $\begin{array}{l}\text { Maize flour }(500 \mathrm{~g}) \text { and roasted } \\
\text { GA flour }(500 \mathrm{~g}) .\end{array}$ & $\begin{array}{l}\text { The two flours were mixed and porridge } \\
\text { was made from the flour using } \\
\text { conventional boiling method }\end{array}$ \\
\hline $\begin{array}{l}\text { GA - Rice } \\
\text { porridge }\end{array}$ & $\begin{array}{l}\text { Rice kernels }(500 \mathrm{~g}) \text { and popped } \\
\text { G.A flour }(500 \mathrm{~g})\end{array}$ & $\begin{array}{l}\text { The two flours were mixed and porridge } \\
\text { was made from the flour using } \\
\text { conventional boiling method. }\end{array}$ \\
\hline $\begin{array}{ll}\text { GA } & \text {-cassava } \\
\text { meal } & \end{array}$ & $\begin{array}{l}\text { Cassava flour }(500 \mathrm{~g}) \text {, roasted } \\
\text { G.A flour }(500 \mathrm{~g})\end{array}$ & $\begin{array}{l}\text { The flours were mixed in a flour blender } \\
\text { and the mixture used in preparation of stiff } \\
\text { porridge using the conventional method }\end{array}$ \\
\hline $\begin{array}{l}\text { GA -cassava- } \\
\text { millet meal }\end{array}$ & $\begin{array}{l}\text { Roasted millet flour }(800 \mathrm{~g}) \text {, } \\
\text { cassava flour }(400 \mathrm{~g}) \text { and popped } \\
\text { G.A flour }(400 \mathrm{~g})\end{array}$ & $\begin{array}{l}\text { The flours were mixed in a flour blender } \\
\text { and the mixture used in preparation of stiff } \\
\text { porridge using the conventional method. }\end{array}$ \\
\hline GA-rice meal & $\begin{array}{l}\text { Rice grain }(500 \text { g) and grain } \\
\text { amaranth }(500 \mathrm{~g}) \text {. }\end{array}$ & $\begin{array}{l}\text { The mixture was boiled together, salted } \\
\text { and spiced as desired }\end{array}$ \\
\hline $\begin{array}{ll}\text { GA } & \text { Tea } \\
\text { Masala } & \end{array}$ & $\begin{array}{l}\text { Freshly ground ginger }(300 \mathrm{~g}), 20 \\
\mathrm{~g} \text { pilau Masala, } 100 \mathrm{~g} \text { popped G.A } \\
\text { flour }\end{array}$ & $\begin{array}{l}\text { Fresh ginger pounded in a motor to } \\
\text { fineness, mixed with pilau masala and } \\
\text { popped G.A flour molded into tiny } \\
\text { fragments, dried under the sun for } 2 \text { days } \\
\text { and later pounded to powder which was } \\
\text { sieved to get a finer powder }\end{array}$ \\
\hline GA soup & Roasted G.A & $\begin{array}{l}\text { Roasted G.A was soaked in four times its } \\
\text { weight of cold water for one hour. Salt } \\
\text { and spices were added as desired and } \\
\text { mixed to achieve uniform distribution. } \\
\text { The mixture was prepared by boiling for } 5 \\
\text { minutes on high fire and gently simmering } \\
\text { for } 20 \text { minutes until most of the water was } \\
\text { absorbed and the amaranth grains were } \\
\text { puffed up. The cover was removed and the } \\
\text { mixture was gently stirred to allow some } \\
\text { of the remaining water to evaporate. } \\
\text { Margarine was added melted into the now } \\
\text { thick mixture. The mixture was then } \\
\text { strained through a sieve to get a thick } \\
\text { creamy soup as the final product }\end{array}$ \\
\hline GA paste & $\begin{array}{l}\text { Roasted sesame }(1000 \mathrm{~g}) \text {, roasted } \\
\text { groundnuts }(500 \mathrm{~g}) \text { and popped } \\
\text { G.A flour }(200 \mathrm{~g})\end{array}$ & $\begin{array}{l}\text { Roasted sesame and roasted groundnut } \\
\text { were mixed and milled into a thin paste to } \\
\text { popped G.A flour was added to form a } \\
\text { thicker paste for use as a spread }\end{array}$ \\
\hline $\begin{array}{l}\text { GA-peanut- } \\
\text { bean snack }\end{array}$ & 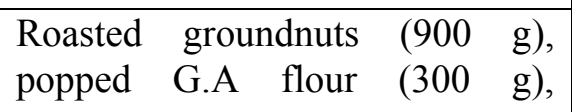 & $\begin{array}{l}\text { Decorticated beans to which water, salt } \\
\text { and spices had been added were boiled }\end{array}$ \\
\hline
\end{tabular}




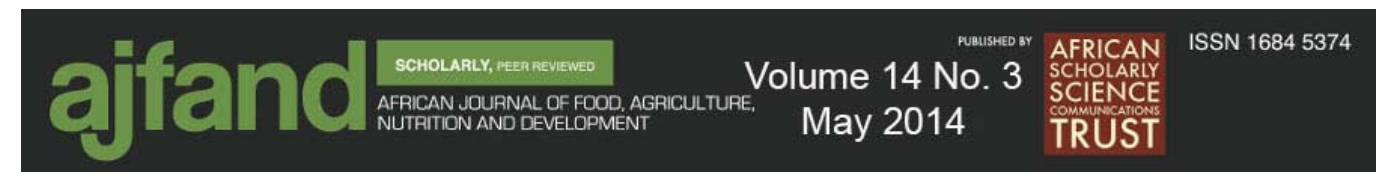

\begin{tabular}{|l|l|l|l|}
\hline & $\begin{array}{l}\text { decorticated beans }(300 \mathrm{~g}) \\
\left(\begin{array}{l}30 \mathrm{~g}) \text {, water, margarine and } \\
\text { assorted spices }\end{array}\right.\end{array}$ & $\begin{array}{l}\text { ready. The excess water was removed and } \\
\text { then the beans were cooled, mashed, while } \\
\text { mixing with GA flour. Resulting mash } \\
\text { was shaped into tiny fragments and dried. } \\
\text { The dry product was prepared by deep } \\
\text { frying until crispy }\end{array}$ \\
\hline $\begin{array}{l}\text { GA Leaf } \\
\text { Powder-Peanut } \\
\text { sauce }\end{array}$ & $\begin{array}{l}\text { Dry GA leaf Powder }(200 \mathrm{~g}), \\
\text { peanut paste }(1 \mathrm{~kg}) .\end{array}$ & $\begin{array}{l}\text { Ingredients thoroughly mixed with 250 } \\
\text { ml of water in a clean saucepan and boiled } \\
\text { at medium heat for 30 minutes with } \\
\text { continuous stirring. Salt added to desired } \\
\text { level. }\end{array}$ \\
\hline
\end{tabular}

Table 2: Foods identified to fill identified dietary gaps

\begin{tabular}{ll}
\hline Nutrient & Foods \\
\hline Zinc & Sesame, soybeans, groundnuts, ginger \\
Calcium & Sesame, soybeans \\
Niacin & Peanut, millet \\
Lipids & Sesame, soybeans \\
Iron & Sesame \\
\hline
\end{tabular}




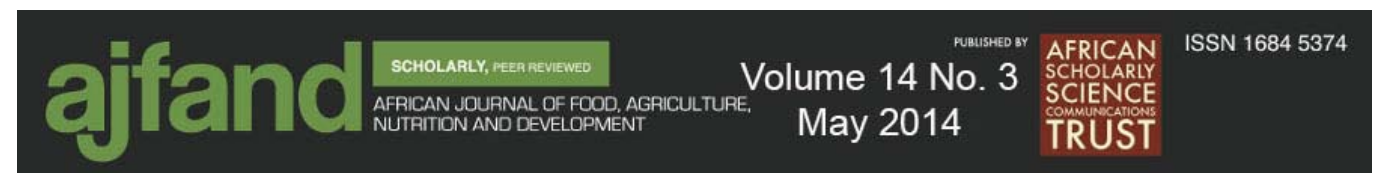

Table 3: Sensory scores for grain amaranth containing products developed

\begin{tabular}{|c|c|c|c|c|c|}
\hline \multirow[t]{2}{*}{ PRODUCT } & \multicolumn{5}{|c|}{ SENSORY ATTRIBUTES $(\mathrm{n}=54)$} \\
\hline & Texture & Flavor & Appearance & Odor & $\begin{array}{c}\text { Overall } \\
\text { acceptability }\end{array}$ \\
\hline Chapatti & 8 & 8.3 & 9 & 7.5 & 8.2 \\
\hline Baggia & 8.3 & 7.3 & 8.8 & 8 & 8.1 \\
\hline Pancakes & 7 & 8.8 & 8.3 & 7.8 & 7.9 \\
\hline Balls & 8.8 & 9 & 7.8 & 8 & 8.4 \\
\hline Sauce & 7.3 & 7.3 & 9 & 8.5 & 8 \\
\hline \multicolumn{6}{|l|}{ Sesame Instant } \\
\hline porridge & 8.8 & 8 & 7.3 & 8.8 & 8.2 \\
\hline Millet porridge & 7.3 & 8.3 & 8.8 & 7.8 & 8 \\
\hline \multicolumn{6}{|l|}{ G.A-Maize } \\
\hline porridge & 7 & 7.3 & 7.3 & 8.5 & 7.5 \\
\hline G.A Rice porridge & 7.5 & 7.5 & 7.3 & 8.8 & 7.8 \\
\hline G.A Cassava meal & 8.5 & 8.8 & 7 & 8 & 8.1 \\
\hline \multicolumn{6}{|l|}{ G.A-Millet- } \\
\hline Cassava meal & 8 & 8.8 & 7.8 & 8.3 & 8.2 \\
\hline G.A Rice meal & 7.5 & 8.3 & 8.8 & 7.8 & 8.1 \\
\hline G.A Tea Masala & 9 & 8.5 & 8.3 & 9 & 8.7 \\
\hline G.A Soups & 7.5 & 8.3 & 9 & 7 & 7.9 \\
\hline G.A Paste & 7 & 8.8 & 8.3 & 8.9 & 8.2 \\
\hline G.A Snack & 7.8 & 8 & 8.5 & 8.3 & 8.1 \\
\hline \multicolumn{6}{|l|}{ G.A Leaf powder- } \\
\hline peanut sauce & 8 & 7.3 & 8 & 7.5 & 7.7 \\
\hline
\end{tabular}




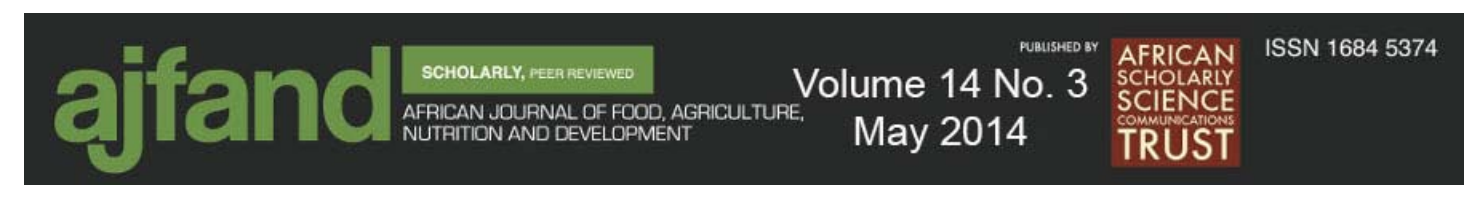

Table 4: Energy and nutrient content of developed, proximate and mineral composition per 100g of the developed products

\begin{tabular}{lllllllllll}
\hline Grain amaranth product & $\begin{array}{l}\text { Energy } \\
(\text { Kcals })\end{array}$ & $\begin{array}{l}\text { Protein } \\
(\mathrm{g})\end{array}$ & $\begin{array}{l}\text { Fat } \\
(\mathrm{g})\end{array}$ & $\begin{array}{l}\text { Carbohydrates } \\
(\mathrm{g})\end{array}$ & $\begin{array}{l}\text { Fiber } \\
(\mathrm{g})\end{array}$ & $\begin{array}{l}\text { Ash }(\mathrm{g}) \\
\text { Chapatti }\end{array}$ & $\begin{array}{l}\text { Moisture } \\
(\mathrm{g})\end{array}$ & $\begin{array}{l}\text { Zn } \\
(\mathrm{mg})\end{array}$ & $\begin{array}{l}\text { Fe } \\
(\mathrm{mg})\end{array}$ & $\begin{array}{l}\text { Ca } \\
(\mathrm{mg})\end{array}$ \\
Baggia & 499.81 & 8 & 16.41 & 69.2 & 3.8 & 1.48 & 31.2 & 1.1 & 2.5 & 46.6 \\
Pancakes & 453.36 & 3.38 & 38.8 & 22.65 & 2.94 & 1.8 & 24.38 & 0.7 & 1.8 & 34.8 \\
Sesame balls & 441 & 11.29 & 24 & 44.96 & 8.11 & 3.1 & 5.43 & 3.35 & 7.47 & 383 \\
Bean sauce & 453.59 & 17.05 & 4.13 & 87.1 & 4.72 & 6.06 & 3.72 & 1.26 & 3.05 & 68.1 \\
Sesame Instant porridge & 428.7 & 12.6 & 22.49 & 43.97 & 12.6 & 2.2 & 86 & 3.7 & 8.57 & 373.6 \\
Millet porridge & 394.26 & 12.2 & 5.64 & 73.7 & 9.07 & 2.9 & 85.2 & 2.87 & 7.61 & 86.5 \\
Maize porridge & 366 & 10.25 & 5.44 & 69 & 1.37 & 2.7 & 88 & 2.3 & 5 & 83 \\
Rice porridge & 400.5 & 9.76 & 4.22 & 80.9 & 1.7 & 1.1 & 89.4 & 1.84 & 3.98 & 84.5 \\
Cassava meal & 377.55 & 9.1 & 3.95 & 76.4 & 3.18 & 2.82 & 42 & 2.1 & 3.94 & 50.75 \\
Millet-Cassava meal & 399.22 & 9.11 & 3.95 & 81.81 & 8.07 & 2.7 & 40.3 & 2.12 & 3.94 & 50.75 \\
Rice meal & 388.12 & 9.76 & 4.22 & 77.8 & 1.19 & 2.6 & 45 & 1.84 & 3.98 & 84.5 \\
Ginger Masala & 363.24 & 9.985 & 7.29 & 64.4 & 7.83 & 4.4 & 7.58 & 3.6 & 168 & 125 \\
Soup & 395.42 & 0.45 & 0.54 & 97.2 & 0.58 & 1.25 & 90.26 & 2.6 & 8 & 17 \\
Sesame-peanut Paste & 543 & 18.39 & 42.6 & 21.5 & 2.76 & 3.4 & 2.49 & 5.45 & 10.2 & 603.3 \\
Bean-peanut Snack & 463.7 & 20.15 & 29.8 & 28.73 & 17.5 & 3.83 & 3.23 & 2.64 & 3.65 & 82.3 \\
Peanut sauce & 534 & 21.72 & 45.2 & 10.1 & 8.2 & 6 & 6.9 & 3.31 & 2.26 & 68.1 \\
\hline
\end{tabular}




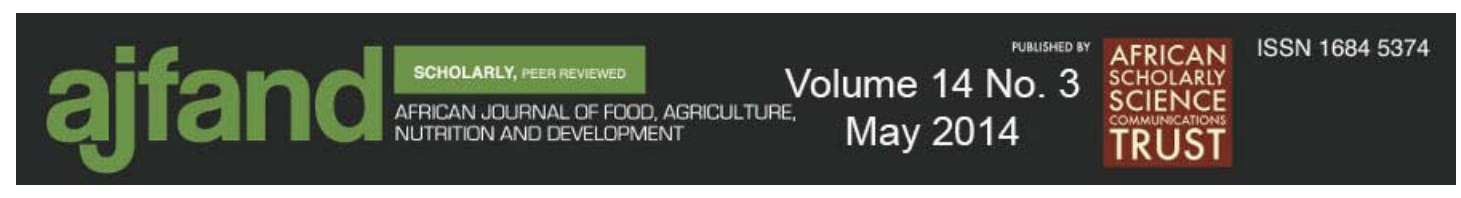

Table 5: Nutrient changes due to grain amaranth incorporation

Grain amaranth product Percentage change in Energy/Nutrients due to amaranth incorporation

\begin{tabular}{|c|c|c|c|c|c|c|}
\hline & Energy & Protein & Fat & Zinc & Iron & Calcium \\
\hline Chapatti & 11.9 & $9.64 *$ & 10.8 & 96.4 & 166 & 288.3 \\
\hline Baggia & 45.8 & $6.7 *$ & 24.6 & 25.3 & 55.2 & $28.2 *$ \\
\hline Pancakes & 19.5 & 293 & 32.4 & 250 & 445.4 & 284.5 \\
\hline Sesame balls & $-7.35^{*}$ & 32.8 & $-4 *$ & -6.9 & $0.95 *$ & $-22.6^{*}$ \\
\hline Bean sauce & 215 & 86.14 & 282.4 & 18.9 & 23 & $9.84 *$ \\
\hline \multicolumn{7}{|l|}{ Sesame Instant } \\
\hline porridge & -9.9 & 48.6 & $-6.25^{*}$ & $3.1^{*}$ & 15.7 & $-24.4^{*}$ \\
\hline Millet porridge & $5.7^{*}$ & 13.1 & 32.7 & 9.1 & 93.1 & 517.9 \\
\hline Maize porridge & $1.38^{*}$ & 47.8 & 40.9 & 32.95 & 110.1 & 1085.7 \\
\hline Rice porridge & 9.4 & 64 & 197.2 & 129.4 & 1037.14 & 745 \\
\hline Cassava meal & 136 & 569.1 & 1310.7 & 517.6 & 1359 & 217.5 \\
\hline Millet-cassava meal & 32.2 & 19.5 & 34.8 & 13.4 & 44.9 & 245.9 \\
\hline Rice meal & $6^{*}$ & 64 & 197.2 & 130 & 1037 & 745 \\
\hline Ginger masala & 8.42 & 11.2 & 71.9 & $-1.09^{*}$ & -15.2 & $9.65^{*}$ \\
\hline Sesame-peanut Paste & $-5^{*}$ & $-4.2 *$ & -12.3 & -7.3 & $-3.8 *$ & $-10.9 *$ \\
\hline Bean-peanut Snack & $0.8^{*}$ & $6.9^{*}$ & -10.95 & $3 *$ & 56.6 & $45.1^{*}$ \\
\hline Peanut sauce & -8.72 & $-8.28 *$ & $-8.98 *$ & $3.4^{*}$ & $7.62 *$ & $26.1 *$ \\
\hline
\end{tabular}

*Changes not significantly different at $\alpha=0.05$ 


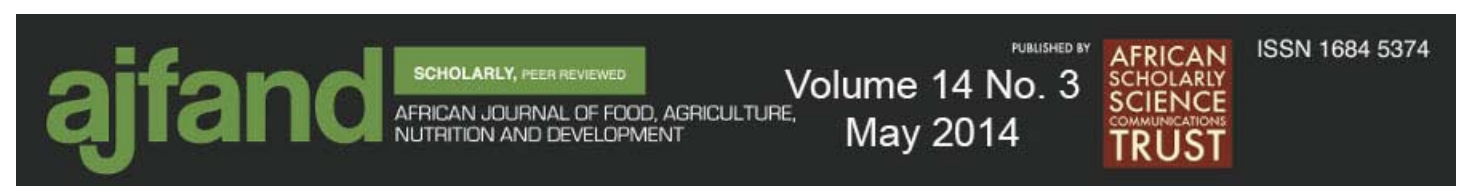

Table 6: Farmer rating of grain amaranth containing recipes

\begin{tabular}{|c|c|c|c|c|}
\hline \multirow{3}{*}{$\begin{array}{l}\text { Product } \\
\text { Chapatti }\end{array}$} & \multicolumn{4}{|c|}{ Score on 5 point Scale } \\
\hline & Kamuli & Apac & Nakasongola & Overall \\
\hline & 4.7 & 5 & 5 & 4.9 \\
\hline Baggia & 4.5 & 4.3 & 4.5 & 4.4 \\
\hline Pancake & 5 & 4.5 & 4.7 & 4.7 \\
\hline Sesame balls & 5 & 5 & 5 & 5 \\
\hline Soup & 3.5 & 4.5 & 4 & 4 \\
\hline Sesame instant porridge & 5 & 5 & 4.5 & 4.8 \\
\hline Rice Porridge & 4.5 & 4.5 & 4.5 & 4.5 \\
\hline Maize Porridge & 5 & 5 & 5 & 5 \\
\hline Millet porridge & 5 & 5 & 5 & 5 \\
\hline Peanut sauce & 3.5 & 4 & 4.5 & 4 \\
\hline Bean sauce & 4 & 4 & 3.5 & 3.8 \\
\hline Rice meal & 3.5 & 3 & 3.5 & 3.3 \\
\hline Cassava meal & 5 & 5 & 5 & 5 \\
\hline Millet-Cassava meal & 5 & 5 & 5 & 5 \\
\hline Ginger Masala & 5 & 4 & 4.5 & 4.5 \\
\hline Paste & 4 & 4.5 & 4 & 4.2 \\
\hline Bean peanut snack & 4.5 & 4 & 5 & 4.5 \\
\hline
\end{tabular}




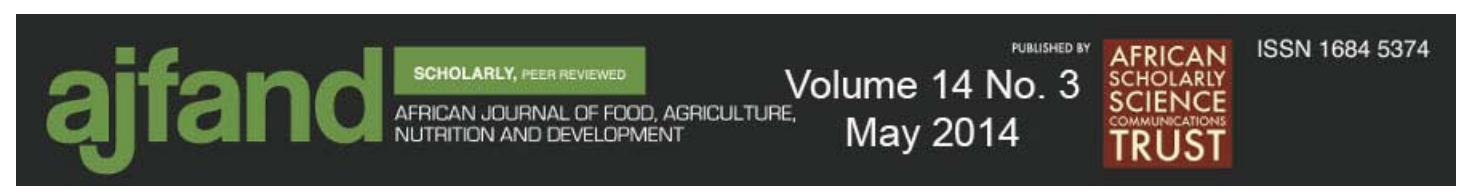

Table 7: Farmer group acceptability scores for different grain amaranth products

\begin{tabular}{|c|c|c|c|c|}
\hline \multirow[t]{2}{*}{ Product } & \multicolumn{4}{|c|}{ Score on 5 point Scale } \\
\hline & Kamuli & Apac & Nakasongola & Overall \\
\hline Chapatti & 5 & 5 & 5 & 5 \\
\hline Baggia & 4.5 & 4.7 & 4.5 & 4.6 \\
\hline Pancake & 4.5 & 4.5 & 5 & 4.7 \\
\hline Sesame balls & 5 & 5 & 5 & 5 \\
\hline Soup & 3.5 & 4 & 4 & 3.8 \\
\hline Sesame instant porridge & 5 & 5 & 4.5 & 4.8 \\
\hline Rice Porridge & 5 & 4.5 & 4.5 & 4.7 \\
\hline Maize Porridge & 4.5 & 4.5 & 4 & 4.3 \\
\hline Millet porridge & 4.5 & 4.5 & 4.5 & 4.5 \\
\hline Peanut sauce & 4 & 4 & 4.5 & 4.2 \\
\hline Bean sauce & 4 & 4 & 4 & 4 \\
\hline Rice meal & 3.5 & 4.5 & 4 & 4 \\
\hline Cassava meal & 5 & 5 & 5 & 5 \\
\hline Millet-Cassava meal & 5 & 5 & 5 & 5 \\
\hline Ginger Masala & 5 & 4.5 & 5 & 4.8 \\
\hline Paste & 4 & 4.5 & 4.5 & 4.3 \\
\hline Bean peanut snack & 4 & 4.5 & 5 & 4.5 \\
\hline
\end{tabular}




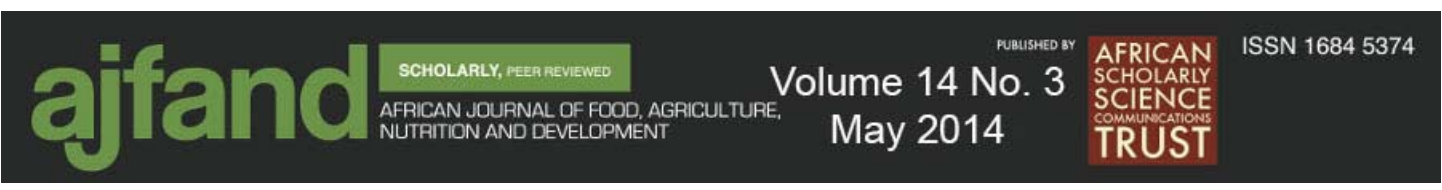

\section{REFERENCES}

1. Myers L Grain amaranth, A Lost Crop of the Americans published by the Jefferson Institute, Columbia, MO, www.jeffersoninstitute.org. 2010. Accessed August 2012.

2. NRC. National Research Council. Amaranth Modern Prospects for Ancient Crop. Washington DC: National Academy Press. 1984.

3. Teutonico RA and D Knorr Amaranth: composition, properties and applications of a rediscovered food crop. Food Tech. 1985; 39: 49-61.

4. WHO. World Health Organisation. Guiding principles for complementary feeding of breastfed child.

http://www.who.int/nutrition/publications/guiding principles compfeeding breastfed.pdf 2003. Accessed August 2012

5. Becker R, Wheeler EL, Lorenz K, Stafford AE, Grosjean OK, Betschart AA and RM Saunders A compositional study of amaranth grain. J. Food Sci. 1981; 46: 1175 1180 .

6. Muyonga J, Nabakabya D, Nakimbugwe DN and D Masinde Efforts to promote amaranth production and consumption in Uganda to fight malnutrition. Chapter 8. In: G.L. Robertson and J.R Lupien (Eds) Using Food Science and Technology to Improve Nutrition and Promote National Development. IUFoST; http://www.iufost.org/publications/books/documents/IUFoST_Handbook.pdf. 2008.

7. Sustainable Rural Livelihoods Program (SRLP). Annual Report 2004-2005. 2005.

8. Tagwira M, Tagwira F, Dugger $\mathbf{R}$ and $\mathbf{B}$ Okum Using grain amaranth to fight malnutrition. RUFORUM working document. 2006; 1: 201-206.

9. Escudero NL, Zirulnik F, Gomez NN, Mucciarelli SI and MS Ginènez Influence of a protein concentrate from Amaranthus cruentus seeds on lipid metabolism. Exp Biol Med. 2006; 231: 50-59.

10. Martirosyan DM, Miroshnichenko LA, Kulakova SN, Pogojeva AV and VI Zoloedov Amaranth oil application for coronary heart disease and hypertension. Lipids in Health and Dis. 2007; 6: 1-12.

11. Kim HK, Kim MJ, Cho HY, Kim EU and DH Shin Antioxidative and anti-diabetic effects of amaranth (Amaranthus esculantus) in streptozotocin-induced diabetic rats. Cell Biochem Funct. 2006; 24: 195 - 199. 


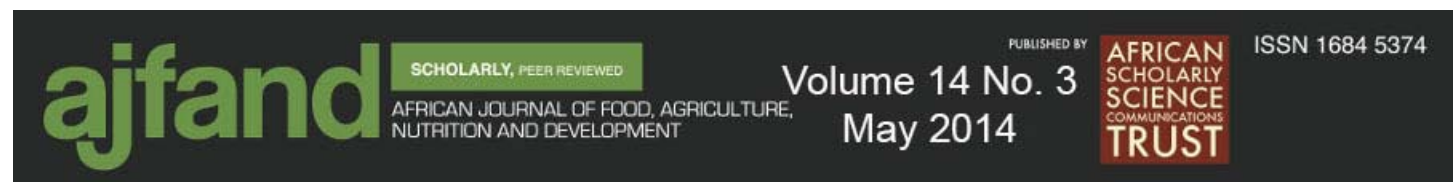

12. Kim HK, Kim MJ and DH Shin Improvement of lipid profile by Amaranth (Amaranthus esculantus) supplementation in Streptozotocin-induced diabetic rats. Ann Nutri Metab. 2006; 50: 277-281.

13. Gibson RS Principles of Nutrition Assessment. New York: Oxford University Press. 2005: 41-64.

14. Hansen R G An Index of Food Quality. Nutr Rev. 1973; 31: 1-7.

15. AOAC. Official Methods of Analytical. Washington DC: Association of Official Analytical Chemists. 2000.

16. Kirk R and R Sawyer Pearson's Chemical Analysis of Foods. Essex: Longman Group Limited. 1991: 26-31.

17. UBOS. Uganda Bureau of Statistics. Uganda Demographic and Health Survey. UBOS, Entebbe, 2011.

18. Harvey $\mathbf{P}$, Rambeloson $\mathbf{Z}$ and $\mathbf{Z}$ Dary The 2008 Uganda Consumption Survey: Determining the dietary patterns of Ugandan Women and children. A2Z: USAID Micronutrient and child blindness project, AED, Washington, D.C. 2010.

19. Ecker O, Weineberger $\mathbf{K}$ and $\mathbf{M}$ Qaim Patterns and determinants of dietary micronutrient deficiencies in rural East Africa. AfJARE. 2010; 4: 175-194.

20. Moron C Food based nutrition interventions at community level. Br J Nutr. 2006; 96:2022.

21. De Groote H, Gunaratna N, Ergano K and D Friesen Extension and adoption of biofortified crops: Quality protein maize in East Africa. Paper Presented at the Joint $3^{\text {rd }}$ Association of Agricultural Economists and $48^{\text {th }}$ Agricultural Economists Association of South Africa Conference, Cape Town, South Africa. 2010.

22. Nzikou JM, Matos L, Bouanga-Kalou G, Ndangui CB, Pambou-Tobi NPG, Kimbonguila A, Silou T, Linder $\mathbf{M}$ and $\mathbf{S}$ Desobry Chemical composition on the seeds and oil of sesame (Sesamun indicum L.) grown in Congo-Brazzaville. Adv. JFST. 2009; 1: 6-11. 